\title{
THE PHILIA PROJECT - FOR THE SUCCESSFUL INTEGRATION OF THE YOUNG THROUGH THEIR EMPOWERMENT AND SOCIAL NETWORK DEVELOPMENT
}

\author{
DANIELA COJOCARU ${ }^{1}$, JORGE M. L. FERREIRA ${ }^{2}$, LYAZID HASSAINI ${ }^{3}$, \\ ION IONESCU ${ }^{4}$, CARINE MORENO SAINT-MARTIN ${ }^{5}$
}

\begin{abstract}
The Philia+ project has been approved for funding within the Erasmus + Programme. Several partners from Belgium, France, Germany, Portugal and Romania (from higher education and social work institutions) have worked to support the academic success and social inclusion of (pre)adolescents aged 13-18 in foster care, and to enhance, preserve and develop their support networks. Training programmes were held for teachers, trainers and researchers involved in the project, as well as for students and social work professionals and young people in difficulty in the care of associations and organizations providing them social and psychological support. The aim has always been to change their position according to the theoretical DPAPC (empowerment of individuals and communities) framework and to the methodological RAC (collaborative research-action) framework, in order to enable them to understand the mechanism of the social determinism of success and failure and to enhance their support networks. We managed to create two training modules, teasers of experienced testimonies (focus groups, comprehensive conversations), educational films for the two modules, educational films on accompanying Roma and unaccompanied minors.
\end{abstract}

Keywords: social work, social integration, teenagers, social network, autonomy, mutual learning.

1 Professor Ph.D., Department of Sociology and Social Work, "Alexandru Ioan Cuza" University of Iasi, Romania, E-mail: dananacu@gmail.com

2 Professor, Diretor Doutoramento em Serviço Social, Escola de Sociologia e Políticas Públicas, Lisabona, Portugal, e-mail: Jorge.Manuel.Ferreira@iscte-iul.pt

3 Professor, Cooordination relations et mobilités internationales C.É.R.I.S.È.S., Haute Ecole de Bruxelles, Belgique, E-mail: lhassaini@he2b.be

4 Professor Emeritus, "Alexandru Ioan Cuza" University of Iasi, Romania, E-mail: ion@uaic.ro

5 Docteur en Psychopathologie et Sciences de l'Education, chercheuse à ERASME, Institut de Travail social France, E-mail: carinestmartin@gmail.com 


\section{Resumé}

Le projet Philia+ a été approuvé pour un financement dans le cadre du programme Erasmus+. Plusieurs partenaires de Belgique, France, Allemagne, Portugal et Roumanie (issus d'établissements d'enseignement supérieur et d'assistance sociale) ont œuvré pour soutenir la réussite scolaire et l'inclusion sociale des (pré)adolescents âgés de 13 à 18 ans, placés en famille d'accueil, pour améliorer, préserver et développer leurs réseaux de soutien. Des programmes de formation ont été organisés pour les enseignants, les formateurs et les chercheurs impliqués dans le projet, ainsi que pour les étudiants et les professionnels du travail social et les jeunes en difficulté pris en charge par des associations et des organisations leur apportant un soutien social et psychologique. L'objectif a toujours été de faire évoluer leur position selon le cadre théorique DPAPC (développement du pouvoir d'agir de personnes et des communautés) et selon le cadre méthodologique RAC (recherche action collaborative), afin leur permettre de comprendre le mécanisme du déterminisme social de la réussite et l'échec et d'améliorer leurs réseaux de soutien. Les membres du projet ont réussi à créer deux modules de formation, des teasers de témoignages d'expérience, groupes de discussion, conversations compréhensives, des films pédagogiques pour les modules, films pédagogiques sur l'accompagnement des Rroms et mineurs non accompagnés.

Mots-clés: travail social, intégration sociale, adolescents, réseau social, autonomie, apprentissage mutuel.

\section{Rezumat}

Proiectul Philia + a fost finanțat în cadrul Programului Erasmus +. Parteneri din Belgia, Franța, Germania, Portugalia și România (din instituții de învățământ superior și de asistență socială) au lucrat pentru formarea studenților din domeniul asitenței sociale și pentru incluziunea socială a (pre)adolescenților cu vârste cuprinse între 13-18 ani aflați în sistemul de protecție socială și pentru a spori, păstra și dezvolta rețelele de sprijin. Au fost organizate programe de instruire pentru profesori, formatori și cercetători implicați în proiect, precum și pentru studenți, profesioniști în domeniul asistenței sociale și tineri în dificultate aflați în îngrijirea asociațiilor și a organizaţiilor care le oferă suport social și psihologic. Scopul a fost acela de a-i schimba pe cei implicați, în conformitate cu cadrul teoretic DPAPC (dezvoltarea puterii de a acționa a persoanelor și comunităților) și cu cadrul metodologic RAC (cercetare-acțiune colaborativă), pentru a le permite să înțeleagă mecanismul determinismului social al succesului și eșecului și pentru a îmbunătăți rețelele de asistență ți sprijin. Membrii proiectului au reușit crearea a două module de instruire, teasere de mărturii, focus grupuri, conversații comprehensive, filme educaționale pentru module, filme privind acompanierea romilor şi a minorilor neînsoțiți.

Cuvinte cheie: asistență socială, integrare socială, adolescență, rețea socială, autonomie, învățare reciprocă.

\section{Introduction}

According to Paul Ricoeur (1995), "suffering is more than physical or psychological pain; it is also as a decrease or even annihilation of the power to act, which is experienced as an attack on the integrity of the self". The 
empowerment of individuals and communities grounds the Philia project and guides its theoretical and methodological framework. The Philia project was proposed and led by the Toulouse-based school for social workers: ERASME, Institut du travail social. Sharing and comparing knowledge and practices in the field of social work is the project approach aimed at meeting the requirements for the collection of knowledge on the life experience of people in difficulty. More comprehensive, inclusive and innovative knowledge and approaches are thus developed.

The nature of the project and its value substantiation are linked to the protection of the rights of children and young people in difficulty, to the fight against social exclusion and discrimination. The European scale of the project consists of the creation of common content, by the mobility of the students and faculty from the participating countries, by exchanging information and experiences. Context analysis in the countries participating in the Philia project revealed three components of young people's power to act: social networks, school education, interculturalism. The project partners considered it important to support the power of young people in difficulty and future social workers to act by supporting and developing strategic networks (family, caregivers, friends, social professionals, academics, etc. $)^{6}$.

The Philia project aimed to strengthen the dynamics of inclusion, by developing the abilities and skills of social work professionals to embrace better integration practices addressed to young people with social, relationship and learning difficulties. The project was designed to support the social commitment of higher education institutions, of social work associations and organizations to promote intercultural and civic skills in the field. Higher education and research institutions in the field of social work, as well as child and young people protection institutions have rallied in all partner countries (Belgium, France, Germany, Portugal, and Romania). The educational resources, tools and methods developed are freely accessible and can improve training content ${ }^{7}$.

The goal was to provide a more inclusive environment for people in difficulty, where their rights, involvement and dignity would be better respected.

The teaching portfolios developed within the project aimed to provide knowledge and professional skills to students to boost the social environment in which they work. The knowledge and skills were connected through systemic multi-actor approaches, integrating interactions within different groups and forms of participatory learning based on multimedia supports, on new information and communications technologies. The objectives were: (1) to provide support for the academic success and inclusion of (pre)adolescents in foster care institutions; (2) to support, preserve and develop various support networks.

6 https://www.facebook.com/506922683159468/videos/431275214355556

7 www.philiaplus.org; https://www.fssp.uaic.ro/images/fssp/stiri/prezentarea_proiectului_ pe_site_UAIC.pdf 
Training sessions were held between 2017 and 2020 for faculty, trainers, researchers, students and young people in difficulty involved in the project, intensive training programs were implemented, the key elements of the training modules were experimented on by bringing together all those involved, who have incessantly contributed to training adjustment to the challenges of social innovation and professionalization.

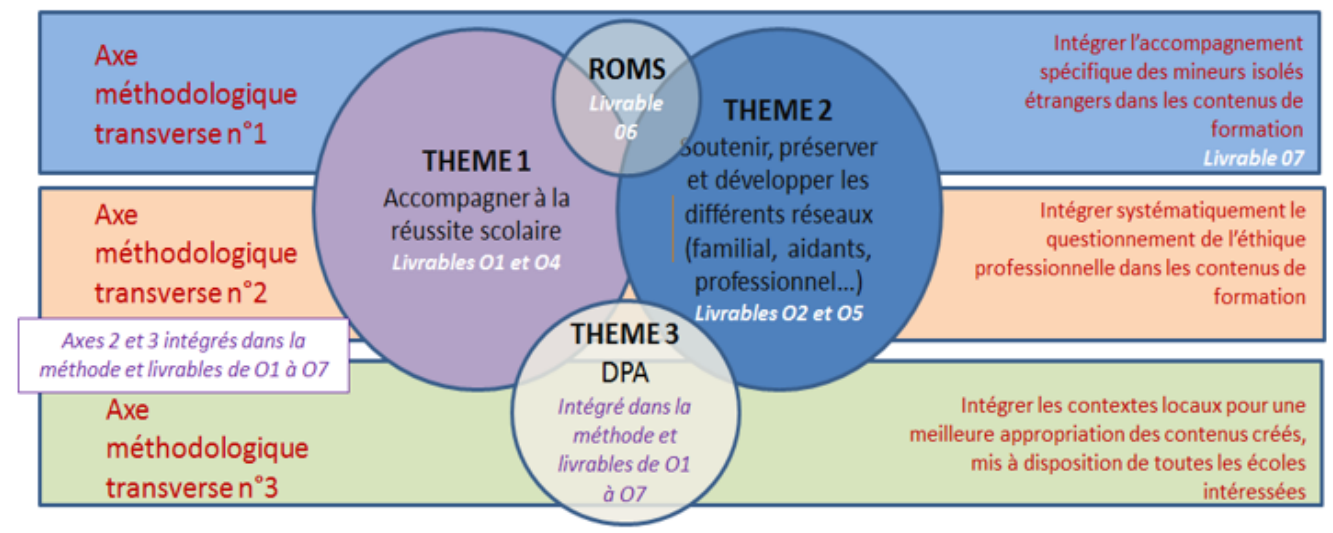

Figure 1. PHILIA Project Rational

The training modules have been tested on the target audience of the Philia project. All intellectual products (teaser of testimonials, focus groups, comprehensive conversations, teaching films for modules 1 and 2, documentaries on accompanying Roma or unaccompanied minors, etc.) are available on websites and are freely downloadable (www.philiaplus.org). They were developed together by online cooperation and one-week face-to-face meetings of project partners. During the three years of the project, methods were crossed (hybridized), information was collected and databases were developed, training modules were built, experiments, adjustments, validations and standardizations of methods and modules took place, now followed by their actual application in social work schools.

\section{Empowerment of individuals and communities (DPAPC) and collaborative research-action (RAC)}

The DPAPC model is inspired by the philosophy of fighting social exclusion that allows an individual in difficulty to participate in changing their own life, in taking responsibility. Yann Le Bossé is the designer of this approach. The model integrates the principle of collaboration by promoting/encouraging creativity and by continuously adapting one's professional position to changes and transformations in society. Social intervention based on the DPAPC approach focuses on several axes:

- Defining the problem (What is the problem?);

- Actors in context (Who are they? What do they have to lose? What do they have to win?); 
- Context (What can we do here and now?);

- Awareness raising actions (Are the identified problem and the solutions found enlightening? What concrete actions should be taken?).

"If the social worker wants to act competently and usefully in current practical situations, they must possess knowledge and good practices regarding what is happening and why, which means that they must have theoretical and practical thinking. Otherwise, they intervention turns into a form of disorganized puzzle of experiences, which eventually leads to spontaneous practices" (Viscarret, 2008, p. 20).

How can the power to act of young people in difficulty be developed and strengthened? Context analysis in the countries participating in the project enabled us to conclude that it is important to develop professional skills in future social workers (De Robertis, 2007), to mobilize the dynamics of resilience of young people faced with school failure, their ability to resort to social support networks, to support effective social practices used by educators, to review their initial and continuing training, the concrete ability of individuals (individually or collectively) to exercise greater control over what is important to them, their loved ones or their community (Le Bossé, 2003; 2006).

Specifically, compliance with this assumption is equivalent to considering that both the diagnosis and the solution are no longer the prerogative of the professional, but the product of a negotiation designed to trigger the best possible reaction taking into account the personal resources available. Therefore, the expertise of the supported persons should be acknowledged, their problems should be identified and defined together, stakes should also be identified together, a unit of analysis should be adopted, the point of view and involvement of those concerned in defining problems and finding solutions should be considered, what can change here and now should be determined, awareness should be raised and lessons to be learned should be described. According to Dufort and Le Bossé (2002: 7-31), DPAPC addresses the need to pool individual and collective resources to achieve intentional, planned change. Social intervention involves both the individual and the community (therefore, the two authors have suggested the expression the empowerment of individuals and communities) (Bronfenbrenner, 1977).

The 'actors in context' axis urges social professionals to ask themselves whether their practices target both the concrete social and economic obstacles that young people in difficulty face and their abilities. The second axis requires negotiating the definition of the targeted change and how to achieve it, together with the people concerned and involved (negotiating the targeted change, pace, steps to be taken, instead of 'prescribing'), as the expertise of social professionals and that of the individuals concerned are complementary. Another axis requires the social worker to be aware that no solution is good unless it considers the context and profile of the people concerned. 'Awareness' requires the social worker to provide conditions that could allow those in difficulty to become aware of the personal and structural elements that contribute or have contributed to the 
emergence and maintenance of difficulties and to learn without systematically resorting only to 'assistance'... DPA-PC implementation requires:

- choosing carefully and responsibly the difficulty on which we want to intervene, as the difficulty is also defined by the person concerned and negotiated with those involved, with the social workers, here and now;

- integrating the experiential expertise of the assisted person and their abilities;

- identifying people affected by a context and the network that can help change it;

- identifying the stakes of all those concerned, of those who win or lose if the context changes as the DPAPC strategy is applied.

Building networks is a real potential for promoting and stimulating participation and autonomy. The network can increase the relevance of local knowledge flows for innovation and can reveal socio-spatial and temporal factors that interfere with these flows. Research has demonstrated the importance of social networks for the development of processes of lifestyle transformation and change starting from the multiplication of connections, increasing the importance of the personal network, local assistance subsystems and proximity. A networkbased intervention and DPAPC are a must for empowering, increasing the autonomy of subjects, families and communities, which can allow participatory citizenship.

The Philia project used DPAPC and a methodology based on collaborative research-action - an abductive approach, supported by the theoretical framework of force theory and the sociology of social integration networks. The focus group technique was used to collect the empirical information necessary for a more adequate systematization of the social reality, in order to find adequate and effective solutions to the diagnosed needs of the target individuals and groups. Nowadays, social workers' intervention also relies on new information and communications technologies, which tightens the connections between local communities and citizens through social networks.

The collaborative research-action used in the project aimed at the contribution of research to social transformation, the harmonization of research goals with the desire for change, the promotion of scientific knowledge, joint work - including with the social welfare beneficiaries (Rullac, 2015) the development of an ethical and methodological framework negotiated and accepted by all those involved in the project to understand the context and look for solutions to their problems (Bayard Rodriguez and Ferreira, 2017). RAC brings together social welfare beneficiaries, students, professionals and professorsresearchers who combine their knowledge as reflective practitioners (Donzelot and Estebe, 1994), who question, explain, understand and consider mutual expertise as a core element, and who feed on experiences and expertise through mutual learning (Rullac, 2018, pp. 37-50). 


\section{Training in the field of social work and the related ethical compass}

The purpose of social work training is to help students acquire and use information, using the reflexivity method based on research and adapted to professional practice (Monnink, 2017). In recent decades, there has been an effort to renew professional practices, an orientation towards interdisciplinary practices and partnership.

Reducing social inequalities has become a challenge for the whole of Europe. Since inequalities are high and their tackling is very costly, they cannot be addressed 'overnight' and they require the involvement social work professionals. They need to be addressed, and rightly so, by both the state and people in need, by people in difficulty, since the vulnerable must also be involved in actions designed to diminish inequalities. More precisely, the intervention should also consider the testimonies of the vulnerable when searching for solutions and when identifying strategies designed to improve their position. Any individual who does not have the ability to make fully informed and rational decisions for themselves and does not have the ability to pursue and protect their own interests, also due to the socio-economic context, is considered vulnerable. Not only individuals, but also groups, communities and populations can be vulnerable. Specifically, reference can be made to children at high risk of poverty, to vulnerability to social disintegration processes, to young people who are no longer included in the foster care system, to very poor Roma people, to unaccompanied minors, to homeless individuals, etc. Vulnerability is represented by exposure to risks and uncertainties that can have unwanted consequences on one's quality of life, and that can lead to non-participation in social life, to economic deprivation, to lack of political involvement, to migration...

But helping them does not mean 'alleviating their suffering' (as in charitable approaches) or curing their suffering (as in medical approaches), or denouncing the causes of suffering (as in militant approaches), or eradicating suffering (as in utopian visions)... It can mean providing support for 'overcoming an obstacle', bearing in mind that the obstacle includes both the socio-economic and the personal dimension, here and now. The problem that a person faces here and now requires action on structural issues (for example, amending laws, allocating budgetary resources, facilities, services, etc.), but also on personal difficulties. When the change expected by a person or by a team requires changing one or several components of the environment, then the social worker focuses on them. When the envisaged change depends on the ability of that person or of that group, then the social worker helps them to acquire such skills.

The specificity of the DPAPC approach consists of redefining the goal of social workers' practices. Most social problems are caused by the current ways of accessing and distributing resources (financial, material, information, etc.). Therefore, solving social problems requires structural changes. However, such changes exceed the competences of social work professionals, although they are part of the end goal of their mission. There is no question of replacing the decisions or the responsibilities of political actors, but of social professionals, 
beneficiaries and communities getting more actively involved. The exclusive focus of the efforts of social work professionals on people's ability to adapt to their living conditions helps to perpetuate their difficulties. The difficulties that people face can be understood not only in terms of causes, but also in terms of managing effects. These two elements must be considered simultaneously. Social work practitioners have somehow lost sight of the structural aspect of the social problem that affects the person or the community as a whole. This happened during the rise of the 'welfare state'. If the 'welfare state' has not kept its welfare promise, the structural aspect of the social problem affecting the person and the community has returned to the foreground with the emergence of 'new poverty', with rising unemployment, with the emergence of many 'unnecessary normals'...

Social work practitioners considered two major concepts.

The first is based on the 'deficiency hypothesis': a person has adjustment and social integration difficulties due to deficient education, training, knowledge, skills, selfesteem, etc., and in order to 'fix things' that person needs to 'fill these gaps' by means of techniques adapted to the diagnosed problems due to these deficiencies. The corollary of this conception consists in the assumption that, once the deficiency is repaired, that person will no longer have difficulties... In fact, most of the difficulties that people face are of structural and societal origin, and filling the alleged gaps only partially solves the difficulties. People are in the same situation, but... they have one more problem, namely that they failed to overcome the difficulties, despite the help received from social work 'professionals'...

The second relies on the... 'one day' hypothesis. That is, social problems are mainly of structural origin, so it is useless to try to solve the problems of individuals on a case-by-case basis. Therefore, social workers should give priority to social change aimed at changing the established order, considered the main cause of social problems, and people in difficulty must be accompanied and supported to show solidarity and become a force, a counter-power able to overturn, 'one day', the established order. This approach tends to ignore, to deny the individual dimension of people's difficulties. Failure to take into account real personal needs, problems, sufferings means letting people in difficulty face the daily effects of their suffering while waiting for their social causes to disappear... Or, an important part of this suffering is due to people... The corollary of this conception is that, 'one day', the social causes of the problems are expected to disappear with the establishment of a 'new social order'... Yet, nothing guarantees us that replacing one order with another is the solution to eradicate social problems... To sum it up, according to this conception, the person faces problems related to the initial situation at the origin of the difficulties - which remain the same, with problems caused by the difficulties related to personal deficiencies; moreover, they also face prospects that overcoming difficulties depends on structural parameters over which they have no control...

What are the expected practices of social workers today? Social assistance? Restorative? Or emancipatory, adapted to the society in which we live? 
Given the current context, social workers had better promote and support the emancipation of beneficiaries, through practices aimed at their empowerment. They had better turn to the collaborative component of research-action, characterized by the involvement of all actors throughout the intervention process, regardless of their status and functions. A principle-based interdisciplinary intervention is added:

- meeting of different disciplines and intersection of different realities;

- movement of concepts and research object;

- tackling of concepts and object by different actors;

- a metalanguage that, in principle, respects the heterogeneity of knowledge.

The intersection of disciplines makes it possible to have a more comprehensive (less partial) view of existing problems and to avoid restricting oneself to one methodology or one method. Interdisciplinarity relies on the ethics of trust based on the principle of interpersonal relationships and the sharing of values and standards that regulate professional intervention.

Partnership is the paradigm that tests the attitudes of professionals and their identities. Partnership in creating connections among institutions and services aims to promote a common reaction in terms of values, professional attitudes, organization of resources and public and private services. Partnership requires ethics based on the principle of cooperation and the transversality of knowledge and social responses, ethics that includes the subject (the individual) as an active and participative partner of the professional's intervention. Building a partnership involves ethical principles, responsibility, conflict, sharing and difference. Therefore, training social workers based on the DPAPC and RAC methodology requires new skills (Le Bossé, 2006: 87-100):

- to identify the potential of the people involved in the problems,

- to analyze complex situations,

- to implement strategies related to environment, resources, constraints, opportunities,

- to understand political and institutional stakes,

- to connect theoretical findings to real life,

- to analyze the deficiencies of the people concerned,

- to decode contexts and strategies of all actors involved, etc.

\section{Conclusion}

The Philia project aimed to change the position of social workers, to help young people in difficulty to understand the mechanism of social determinism and of personal success, by developing partnerships, by working with the school, and by improving social support networks.

In order to carry out the project, the Philia partners implemented and continuously relied on an ethical compass. The social field cannot function without the integration of ethical questions that stand alongside theory, methodology and working techniques, as well as alongside the results of 
collaborative research-action. The DPAPC-based approach to collaborative research-action (RAC) requires identifying and defining the problem together, by bringing together all stakeholders, actors in contexts, by questioning here and now, by joining knowledge, and by explaining and expressing what is learned from experience. Sharing knowledge and expertise, working on the Self and on one's own experience, feedback on experience ('therapeutic time'), awareness and freedom are required by an ethical compass that guides us towards liberating effects through involvement and empowerment to act safely together. Collaborative research-action and DPAPC bring us together in the social game, help us identify stakes, expose us and enhance our ability to be ethical, invite us to be assertive, to use tools that promote expression and verbalization (linguistic photographs, socio-cognitive conflicts, image theatre, forum, video analyses...).

The use of new information and communications technologies (NICT) in the project required rethinking working methods and techniques, interactions between partners (especially during the covid 19 pandemic), reshaping the organization and questions about information management, forms of access to information. Questions have been raised and are still being raised regarding the security of the information system, the public dimension and the confidentiality of information (guaranteeing unrestricted access to information).

According to the DPA-PC and RAC approach, guidance, success and integration are seen as a dynamic reality in which social, professional and personal problems coexist, which can mean a certain upheaval of the reference values of social professionals. Specifically, they must relinquish the position of 'expert' (who 'knows best what is best' for the other, for others) and take into account the experiential knowledge of the person or community targeted by his or her intervention (Richmond, 2002). This change of paradigm calls into question professional practices without distorting professional identity.

\section{References}

Bayard Rodriguez, M. D. \& Ferreira, J. (2017). La contribution de l'intervention dans les réseaux sociaux et du travail social communautaire au niveau local, social et humain. Revue européenne $d u$ travail social (CESW). DOI: 10.1080/13691457.2018.1423551

Bronfenbrenner, U. (1977). Toward an experimental ecology of human development. American Psychologist, 32(7), 513-531. DOI: 10.1037/0003-066X.32.7.513

De Robertis, C. (2007). Méthodologie de l'intervention en travail social. Bayard.

Donzelot, J., Estebe, P. (1994), L'Etat animateur. Essai sur la politique de la ville. Esprit.

Dufort, F., Le Bossé, Y. (2002). La psychologie communautaire et le changement social. In: Dufort, F., Guay, J. (Eds.), Agir au cœur des communautés, Les Presses de l'Université Laval.

Le Bossé, Y. (2003). De „'habilitation” au „pouvoir d'agir” vers une appréhension plus circonscrite de la notion d'empowerment. Nouvelles Pratiques Sociales, 16(2), 30-51.

Le Bossé, Y. \&Vallerie, B. (2006). Le développement du pouvoir d'agir (empowerment) des personnes et des collectivités: de son expérimentation à son enseignement. Les sciences de l'éducation pour l'ère nouvelle, 39(3), 87-100.

Monnink, H. (2017). La boîte à outils des travailleurs sociaux. Travail social durable et multiméthode. Routledge: Taylor \& Francis. 
Parton, N., O'Byrne, P. (2000). Constructive Social Work: Towards a New Practice. Basingstoke, Macmillan.

Richmond, M.- E. (2002). Les méthodes nouvelles d'assistance. Librairie Félix Alcan.

Ricœur, P. (1995). Le fuste. Éditions Esprit.

Rullac, S. (2015). Les chercheurs ignorants, Les recherches-actions collaboratives. Une révolution de la connaissance. EHES.

Rullac, S. (2018). Recherche Action Collaborative en travail social: les enjeux épistémologiques et méthodologiques d'un bricolage scientifique. Pensée plurielle, $48,37-50$.

Viscarret, J. J. (2007). Modelos y Métodos de Intervención Social. Alianza Editorial. 